\title{
BIOLOGICAL ASPECTS AND LIFE TABLE OF Uroleucon ambrosiae (THOMAS, 1878) AS A FUNCTION OF TEMPERATURE
}

\author{
Alexander Machado Auad ${ }^{1 *}$; Jair Campos de Moraes $^{2}$ \\ ${ }^{1}$ UNOESTE/FCA - Depto. de Biologia Vegetal e Fitossanidade - 19067.175 - Presidente Prudente, SP - Brasil. \\ ${ }^{2}$ UFLA - Depto. de Entomologia, C.P. 37 - 37200.000 - Lavras, MG - Brasil. \\ *Corresponding author <amauad@zipmail.com.br>
}

\begin{abstract}
The aphid Uroleucon ambrosiae (Thomas) is considered a pest of hidroponically-grown lettuce, but basic and applied information on its control are scarce in Brazil. The aim of this study was to determine the effect of different temperatures on biological aspects and life history of $U$. ambrosiae (Thomas) developing on hydroponic lettuce (Lactuca sativa L.) crop. Newly emerged nymphs were placed on 4-cm discs of hydroponic lettuce, var. Verônica, which were maintained on 5-cm Petri dishes, at temperatures of 15,20 and $25^{\circ} \mathrm{C}$ and $14 \mathrm{~h}$ photophase, and inside a greenhouse, within micro-cages at room temperature. The duration of development in all nymphal stages varied inversely to temperature. Nymphs maintained at $20^{\circ} \mathrm{C}$ and $25^{\circ} \mathrm{C}$, had similar development period. However, at fluctuating greenhouse temperatures (daily mean $=21^{\circ} \mathrm{C}$ ), different results were obtained, which was also true for the pre-reproductive, reproductive and post-reproductive periods. Daily and total fertilities at $20^{\circ} \mathrm{C}$ were better in comparison to the other treatments. The highest mortality rate of aphids occurred under greenhouse conditions. The production of 1.28 nymphs per female per day, the time needed for the population to double in size ( $T D=2.77$ days $)$, and the intrinsic rate of population increase $\left(\mathrm{r}_{\mathrm{m}}=0.25\right)$, were similar for in insects maintained at 20 and $25^{\circ} \mathrm{C}$. On the other hand, time interval between generations $(\mathrm{T})$ and the net reproductive rate $\left(\mathrm{R}_{\mathrm{o}}\right)$ were higher at $20^{\circ} \mathrm{C}$. In the greenhouse, even though $\mathrm{T}$ was similar to laboratory conditions at 20 and $25^{\circ} \mathrm{C}$, the $\mathrm{R}_{0}, \mathrm{r}_{\mathrm{m}}$ and $\lambda$ parameters were lower and TD was higher. Based on biological aspects, fertility and life expectancy tables, constant temperature of $20^{\circ} \mathrm{C}$ is the most suitable for U. ambrosiae. Key words: insecta, aphids, biology, climatic factors
\end{abstract}

\section{ASPECTOS BIOLÓGICOS E TABELA DE VIDA DE Uroleucon ambrosiae (THOMAS) EM FUNÇÃO DA TEMPERATURA}

\begin{abstract}
RESUMO: O afídeo Uroleucon ambrosiae (Thomas) é considerado praga em alface de cultivo hidropônico, mas conhecimentos básicos e aplicados que auxiliam no seu controle, são escassos no Brasil. O objetivo do trabalho foi determinar o efeito de diferentes temperaturas a biologia e tabela de vida de $U$. ambrosiae em alface (Lactuca sativa L.) hidropônica. Ninfas recém-emergidas foram colocadas em discos com $4 \mathrm{~cm}$ de diâmetro de folhas de alface hidropôncia cv. Verônica, mantidas em placas de Petri de $5 \mathrm{~cm}$, nas temperaturas de 15, $20 \mathrm{e}$ $25^{\circ} \mathrm{C}$, com $14 \mathrm{~h}$ de fotofase e em casa-de-vegetação em microgaiolas com temperatura ambiente. A duração do desenvolvimento de todos os estágios ninfais variou em razão inversa à temperatura. Quando as ninfas foram mantidas em temperaturas de $20^{\circ} \mathrm{C}$ ou $25^{\circ} \mathrm{C}$, os períodos de desenvolvimento foram similares; no entanto, na temperatura ambiente de casa-de-vegetação (média diária $=21^{\circ} \mathrm{C}$ ), diferentes resultados foram observados. A mesma tendência foi observada para os períodos pré-reprodutivo, reprodutivo e pós-reprodutivo. A fertilidade diária e total a $20^{\circ} \mathrm{C}$ foi melhor quando comparada com as temperaturas constantes de $15^{\circ} \mathrm{C}$ e $25^{\circ} \mathrm{C}$ e a da casade-vegetação. A maior mortalidade do afídeo foi constatada em condições de casa-de-vegetação. A produção de 1,28 ninfas por fêmea por dia, o tempo necessário para duplicar em número ( $\mathrm{TD}=2,77$ dias) e capacidade inata de aumentar em número $\left(\mathrm{r}_{\mathrm{m}}=0,25\right)$, foram similares quando esses insetos foram mantidos a 20 e $25^{\circ} \mathrm{C}$. No entanto, a $20^{\circ} \mathrm{C}$ valores superiores foram observados para o tempo decorrido entre gerações ( $\mathrm{T}$ ) e para a taxa líquida de reprodução $\left(\mathrm{R}_{\mathrm{o}}\right)$. Na casa-de-vegetação, apesar do valor de $\mathrm{T}$ ter sido próximo ao observado em condições de laboratório, a 20 e $25^{\circ} \mathrm{C}$, os parâmetros taxa reprodutiva líquida (Ro), taxa intrínseca de aumento de população $\left(r_{m}\right)$ e taxa finita de aumento $(\lambda)$ foram inferiores, e TD foi superior. Pelos aspectos biológicos e tabela de fertilidade e esperança de vida, a temperatura de $20^{\circ} \mathrm{C}$ é a mais favorável para a espécie $U$. ambrosiae. Palavras-chave: insecta, afídeos, biologia, fatores climáticos
\end{abstract}

\section{INTRODUCTION}

Lettuce (Lactuca sativa L.) is one of the most common and easily found vegetables in Brazilian homes
(Darold et al., 1993). The aphid Uroleucon ambrosiae (Thomas), a pest of various cultivated and wild plants of the family Asteraceae (Peña-Martines, 1992) is among the factors that may cause economical damage to this crop. 
This insect is not only an important vector of the lettuce mosaic virus, but also cause qualitative damage, because excretes and deposit the "honeydew" over the leaves, which encourages the development of the sooty mold, and undervaluate the product.

Temperature is one of the factors that conditions the size of $U$. ambrosiae populations. Highest population densities for this aphid in the hydroponic lettuce condition occur betw een 16.4 and $192^{\circ} \mathrm{C}$ (Auad et al., 2002). Negative correlation between temperature and relative humidity and population density of $U$. compositae (Theobald) was verified by Akashe et al. (1995). This fact indicates that investigating the interaction between temperature and development rate of aphids is essential to understand their population dynamics (Liu \& Meng, 2000).

Because of the great economical importance of $U$. ambrosiae for hydroponic lettuce cultivation in Brazil (Auad et al., 2002), this study was set up to obtain information on biological aspects and on the life table of this aphid under different temperatures, aiming to estimate parameters related to its population growth potential which may back up integrated management programs for the control of this pest under protected cultivation.

\section{MATERIAL AND METHODS}

Nymphs and adults of $U$. ambrosiae were collected from hydroponically-grow lettuce plants. Biological aspects of the aphid were studied in the laboratory by placing 4-cm lettuce leaf discs (cv. Verônica), on 5-cm Petri dishes containing an agar layer (1\%); Leaf discs were replaced every three days. Recently-emerged nymphs were placed on the dishes and maintained in BOD incubators at temperatures of 15,20 and $25^{\circ} \mathrm{C}$, and $14 \mathrm{~h}$ photophase. Samples were observed daily under a stereoscopic microscope. Evaluations included: the number of instars, duration of each instar, duration of the nymphal period, duration of the pre-reproductive, reproductive and post-reproductive periods, longevity, and daily and total nymph production. These aspects were also evaluated in the greenhouse on recently-emerged nymphs placed on hydroponic lettuce plants and individualized in microcages built with transparent PVC tubes, $3 \mathrm{~cm}$ in diameter and $1.5 \mathrm{~cm}$ height, with one end covered by voile fabric and the rim of the other end padded with foam. Cages were attached to the lettuce leaves by aluminum clips. Data on temperature and relative humidity inside the greenhouse were recorded on a thermo-hygrograph. The experiment was set up in a completely randomized design, with 40 replicates per temperature. Data were submitted to analysis of variance differences between means were detected by Tukey test $(P=0.05)$.

The life table calculations were based on Silveira Neto et al. (1976), from laboratory data at 15,20 and $25^{\circ} \mathrm{C}$ and in the greenhouse, with minimum, mean and maximum temperatures equal to 14,21 and $31^{\circ} \mathrm{C}$. The life expectancy table included: number of survivors $\left(\mathrm{L}_{\mathrm{x}}\right)$; number of dead individuals $\left(\mathrm{d}_{\mathrm{x}}\right)$; age structure $\left(\mathrm{E}_{\mathrm{x}}\right)$; life expectancy $\left(\mathrm{e}_{\mathrm{x}}\right)$; and probability of dying at age $\mathrm{x}\left(100 \mathrm{q}_{\mathrm{x}}\right)$, where: $\mathrm{E}_{\mathrm{x}}=\left[\mathrm{L}+\left(\mathrm{L}_{\mathrm{x}+1}\right)\right] / 2 ; \mathrm{e}_{\mathrm{x}}=\mathrm{T}_{\mathrm{x}} / \mathrm{L}_{\mathrm{x}} ; 100 \mathrm{q}_{\mathrm{x}}=\left(\mathrm{d}_{\mathrm{x}} / \mathrm{L}_{\mathrm{x}}\right) \times 100$. The fertility table included the net reproductive rate $\left(\mathrm{R}_{\mathrm{o}}\right)$, time interval between generations $(T)$, intrinsic rate of population increase $\left(r_{m}\right)$, finite rate of increase $(\lambda)$ and time needed for the population to double in size (TD), by means of the age intervals (x), age-specific fecundity $\left(\mathrm{m}_{\mathrm{x}}\right)$ and age-specific survivorship $\left(1_{\mathrm{x}}\right)$, where: $\mathrm{R}_{\mathrm{o}}=\Sigma$ $\left(\mathrm{m}_{\mathrm{x}} \mathrm{1}_{\mathrm{x}}\right) ; \mathrm{T}=\left(\Sigma \mathrm{m}_{\mathrm{x} . \mathrm{x} .} \mathrm{x}\right) / \Sigma\left(\mathrm{m}_{\mathrm{x} x \mathrm{x}} \mathrm{1}_{\mathrm{x}}\right) ; \mathrm{r}_{\mathrm{m}}=\log _{\mathrm{e}} \mathrm{R}_{\mathrm{o}} / \mathrm{T}=\mathrm{In} \mathrm{R}_{\mathrm{o}} / \mathrm{T}$; $\lambda=\mathrm{e}^{\mathrm{rm}} ; \mathrm{TD}=\operatorname{In}(2) / \mathrm{r}_{\mathrm{m}}$.

\section{RESULTS AND DISCUSSION}

\section{Biological aspects in the nymphal stage}

Similarly to aphid species in general, $U$. ambrosiae went through four instars, (Dixon, 1987; Blackman, 1987). The time required for nymphal development, in all instars, was greater at $15^{\circ} \mathrm{C}$ (Table 1), varying inversely with the temperature. This has also been demonstrated for other aphid species by Elliott \& Kieckhefer (1989), Van Steenis \& El-Khawass (1995); and Bueno \& Foureaux (1998).

Second and $3^{\text {rd }}$ instar nymphs, regardless of being reared in the laboratory $\left(20^{\circ} \mathrm{C}\right)$ or in the greenhouse, needed the same time to reach the next stage (Table 1). However, the duration was greater for those nymphs in the $1^{\text {st }}$ and $4^{\text {th }}$ instars submitted to variable temperatures in the greenhouse.

No changes in nymphal developmental period were observed at $20^{\circ} \mathrm{C}$ and $25^{\circ} \mathrm{C}$ for all instars. However, when the greenhouse data $\left(21^{\circ} \mathrm{C}\right)$ were compared with the $25^{\circ} \mathrm{C}$ data, a decrease in duration was observed (Table 1). At similar temperatures, this variation can be attributed to temperature oscillations under greenhouse conditions, but that did not occur in the laboratory. Different responses in Lipaphis erysimi (Kaltenbach) nymphs maintained under constant or variable temperatures were demonstrated by Liu \& Meng (2000), who reported that nymphs reared at constant temperatures of either $8^{\circ} \mathrm{C}$ or $35^{\circ} \mathrm{C}$ did not reach the adult stage. However, when maintained under a variable temperature regime, which included those temperatures at certain times of day, the aphids were able to attain the adult stage. The development of aphids at extreme temperatures under variable regimes has also been demonstrated for Myzus persicae (Sulzer) by Liu \& Meng (1999).

As the temperature increased, the mean duration of the nymphal stage of $U$. ambrosiae was reduced from $16.03\left(15^{\circ} \mathrm{C}\right)$ to 7.33 days $\left(25^{\circ} \mathrm{C}\right)$ (Table 1$)$, resulting in a smaller time interval between each generation $(\mathrm{T})$ at higher temperatures (Table 2), similarly to what has been 
Table 1 - Mean duration, in days, for $1^{\text {st }}, 2^{\text {nd }}, 3^{\text {th }}$ and $4^{\text {th }}$ instar nymphs to develop, pre-reproductive, reproductive and postreproductive periods, daily and total fertility, and longevity of nymphs and adults of Uroleucon ambrosiae, under three constant temperatures, and under greenhouse conditions. $n=40$.

\begin{tabular}{|c|c|c|c|c|}
\hline \multicolumn{5}{|c|}{ Nymphal stage } \\
\hline & \multicolumn{3}{|c|}{ Laboratory } & \multirow[t]{2}{*}{ Greenhouse } \\
\hline & $15^{\circ} \mathrm{C}$ & $20^{\circ} \mathrm{C}$ & $25^{\circ} \mathrm{C}$ & \\
\hline $1^{\text {st }}$ instar & $3.80 \pm 0.13 \mathrm{a}$ & $2.07 \pm 0.06 \mathrm{c}$ & $1.73 \pm 0.09 \mathrm{c}$ & $2.70 \pm 0.09 \mathrm{~b}$ \\
\hline $2^{\text {nd }}$ instar & $4.07 \pm 0.17 \mathrm{a}$ & $2.27 \pm 0.14 \mathrm{bc}$ & $1.93 \pm 0.11 \mathrm{c}$ & $2.47 \pm 0.13 \mathrm{~b}$ \\
\hline $3^{\text {rd }}$ instar & $4.00 \pm 0.14 \mathrm{a}$ & $1.90 \pm 0.06 \mathrm{~b}$ & $1.77 \pm 0.12 b$ & $2.13 \pm 0.01 \mathrm{~b}$ \\
\hline $4^{\text {th }}$ instar & $4.17 \pm 0.14 \mathrm{a}$ & $2.27 \pm 0.08 \mathrm{c}$ & $2.17 \pm 0.11 \mathrm{c}$ & $3.20 \pm 0.12 b$ \\
\hline Nymphal Stage & $16.03 \pm 0.38 \mathrm{a}$ & $8.47 \pm 0.15 \mathrm{c}$ & $7.33 \pm 0.23 d$ & $10.47 \pm 0.18 b$ \\
\hline \multicolumn{5}{|c|}{ Adult stage } \\
\hline Pre-Reproductive & $3.90 \pm 0.18 \mathrm{a}$ & $1.77 \pm 0.09 b$ & $2.16 \pm 0.15 b$ & $2.07 \pm 0.10 \mathrm{~b}$ \\
\hline Reprodutive & $15.57 \pm 1.10 \mathrm{a}$ & $12.23 \pm 0.57 \mathrm{~b}$ & $8.47 \pm 0.62 \mathrm{c}$ & $8.87 \pm 0.92 \mathrm{c}$ \\
\hline Post-Reproductive & $2.07 \pm 0.29 \mathrm{ab}$ & $1.50 \pm 0.19 b$ & $2.93 \pm 0.44 \mathrm{a}$ & $1.17 \pm 0.09 \mathrm{~b}$ \\
\hline Longevity & $21.60 \pm 1.98 \mathrm{a}$ & $15.50 \pm 0.63 b$ & $13.50 \pm 0.69 \mathrm{bc}$ & $12.10 \pm 0.94 \mathrm{c}$ \\
\hline Biological Cycle (nymph + adult) & $37.50 \pm 1.25 \mathrm{a}$ & $23.97 \pm 0.60 \mathrm{~b}$ & $21.10 \pm 0.73 \mathrm{~b}$ & $22.50 \pm 0.97 b$ \\
\hline \multicolumn{5}{|c|}{ Fertility (Number of nymphs produced) } \\
\hline Total & $52.47 \pm 4.46 \mathrm{~b}$ & $83.30 \pm 4.49 \mathrm{a}$ & $29.27 \pm 3.10 \mathrm{c}$ & $37.07 \pm 3.51 \mathrm{c}$ \\
\hline Daily & $3.24 \pm 0.11 \mathrm{c}$ & $6.76 \pm 0.19 \mathrm{a}$ & $3.40 \pm 0.24 \mathrm{c}$ & $4.34 \pm 0.24 \mathrm{~b}$ \\
\hline
\end{tabular}

Means followed by a common letter in the rows did not differ by Tukey test at $5 \%$.

Table 2 - Fertility table for Uroleucon ambrosiae in the laboratory and in the greenhouse.

\begin{tabular}{lrrrr}
\hline & \multicolumn{3}{c}{ Fertility } & Laboratory \\
\hline \multirow{2}{*}{$\begin{array}{l}\text { Parameters } \\
\text { evaluated }\end{array}$} & $15^{\circ} \mathrm{C}$ & $20^{\circ} \mathrm{C}$ & $25^{\circ} \mathrm{C}$ \\
\hline $\mathrm{T}$ & 27.66 & 16.88 & 13.38 & 16.99 \\
$\mathrm{R}_{\mathrm{o}}$ & 39.56 & 70.02 & 26.93 & 25.79 \\
$\mathrm{r}_{\mathrm{m}}$ & 0.13 & 0.25 & 0.25 & 0.19 \\
$\lambda$ & 1.13 & 1.28 & 1.28 & 1.21 \\
$\mathrm{TD}$ & 5.33 & 2.77 & 2.77 & 3.65 \\
\hline
\end{tabular}

$\mathrm{T}$ : Time interval between each generation; $\mathrm{R}_{\mathrm{o}}$ : Net reproductive rate; $r_{m}$ : Intrinsic rate of population increase; $\lambda$ : Finite rate of increase; TD: Time necessary to double in population size (days).

reported observed for Aphis gossypii Glover (Kocourex et al., 1994) and L. erysimi (Godoy, 1999). Nymphs of $U$. ambrosiae maintained at $25^{\circ} \mathrm{C}$ attained the adult stage in half the time necessary for those maintained at $15^{\circ} \mathrm{C}$, which resulted in greater population growth potential.

\section{Biological aspects in the adult stage}

The duration of the pre-reproductive period was longer when females were maintained at $15^{\circ} \mathrm{C}$. A decrease in the reproductive period was verified at higher temperatures: from 15.57 days at $15^{\circ} \mathrm{C}$ to 8.47 days at $25^{\circ} \mathrm{C}$. The post-reproductive period was shorter at $20^{\circ} \mathrm{C}$ than at $25^{\circ} \mathrm{C}$, but not at $15^{\circ} \mathrm{C}$ (Table 1). Not only temperature influences these periods, but also the number of offsprings produced during these time intervals should also be considered. For females kept in the greenhouse, shorter reproductive and longevity periods were observed, while no significant differences were verified for the pre-reproductive and postreproductive periods and for the biological cycle, when compared to the results observed at $20^{\circ} \mathrm{C}$. Therefore, data obtained at the constant temperatures (laboratory) can be utilized to estimate development time for those insects in the adult stage under room conditions (greenhouse), and that would provide supporting information for management strategies against this pest.

Longevity of $U$. ambrosiae was greater at $15^{\circ} \mathrm{C}$ (21.60 days), decreasing to 13.50 days at $25^{\circ} \mathrm{C}$. The biological cycle was longer at $15^{\circ} \mathrm{C}$, when compared to the constant temperatures $\left(20\right.$ and $\left.25^{\circ} \mathrm{C}\right)$ and to the room temperature prevailing in the greenhouse (Table 1).

The total number of nymphs of $U$. ambrosiae produced at $20^{\circ} \mathrm{C}$ was 83.30 nymphs (Table 1 ) with a mean value of 7.94 nymphs per female; at $15^{\circ} \mathrm{C}$ a total of 52.47 nymphs was recorded; at temperature $25^{\circ} \mathrm{C}, 29.27$ nymphs; in the greenhouse, 37.07 nymphs. The greater daily $U$. ambrosiae nymph production was verified at $20^{\circ} \mathrm{C}$. These differences, i.e., a greater number of offspring at the $20^{\circ} \mathrm{C}$ temperature, may lead to a greater growth potential and, since under field conditions this species has to face changing conditions, even when the mean temperature is close to $20^{\circ} \mathrm{C}$, the number of offsprings might be reduced.

\section{Life expectancy table}

The greater longevity of $U$. ambrosiae on lettuce plants was observed when the individuals were main- 
tained at $15^{\circ} \mathrm{C}$ (48 days), followed by those maintained in the greenhouse (30 days) and in the laboratory at $20^{\circ} \mathrm{C}$ and $25^{\circ} \mathrm{C}$ (29 and 26 days, respectively) (Figure 1).

The greatest life expectancies $\left(\mathrm{e}_{\mathrm{x}}\right)$ for $U$. ambrosiae were $29.95,19.98,17.15$, and 17.93 days at the nymphal stage; and 19.47, 12.18, 11.10, and 9.89 days at the adult stage (Figure 1). These values were recorded on the $2^{\text {nd }}, 1^{\text {st }}, 2^{\text {nd }}$, and $3^{\text {rd }}$ observation days for nymphs, and on the $17^{\text {th }}, 9^{\text {th }}, 9^{\text {th }}$ and $12^{\text {th }}$ days for adults, when maintained at temperatures of 15,20 and $25^{\circ} \mathrm{C}$ in
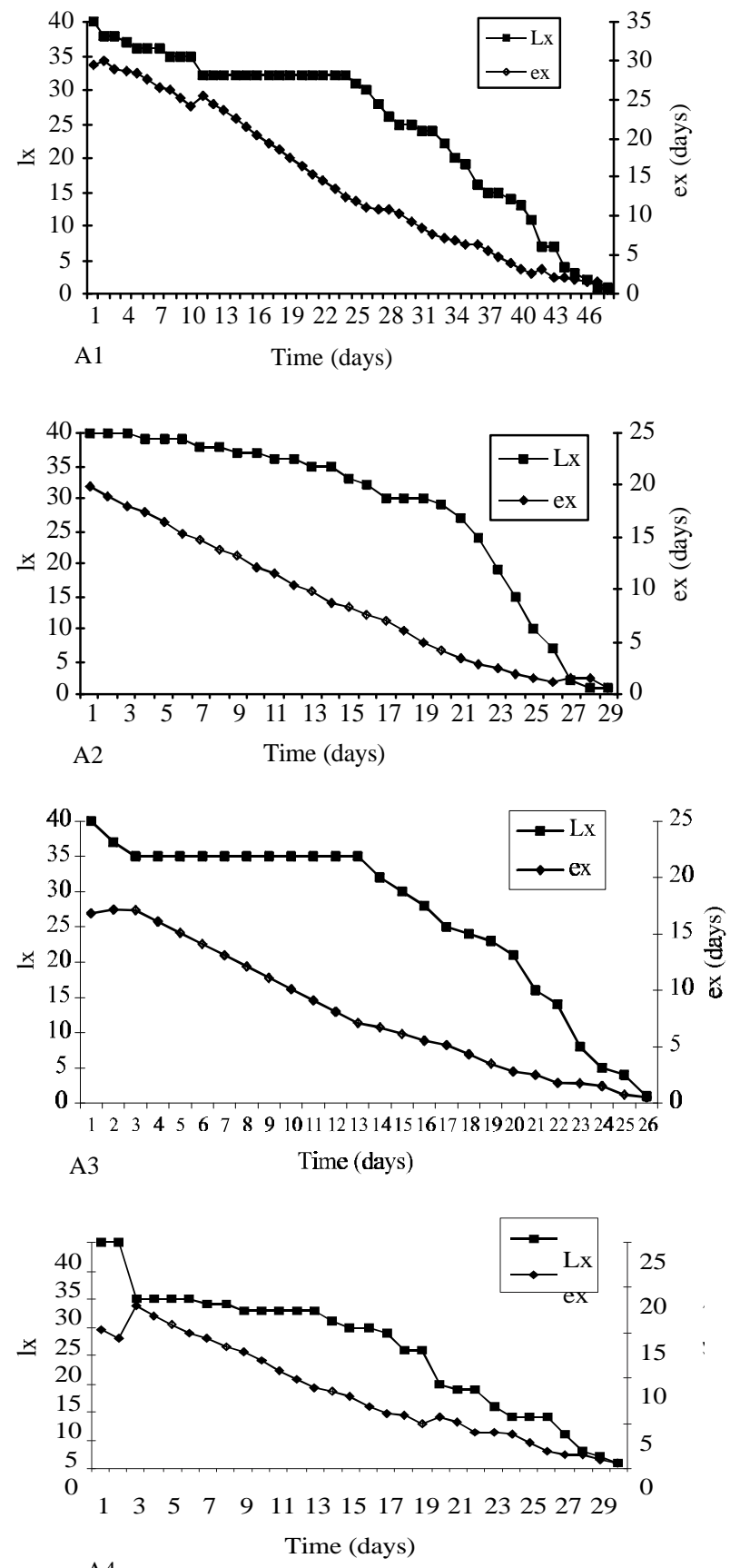

the laboratory, and in the greenhouse, respectively. The probability of death occurring $\left(100 q_{x}\right)$ for these individuals before the established time was null, except for the adult stage at $20^{\circ} \mathrm{C}$ and for the nymphal stage at $25^{\circ} \mathrm{C}$, with values of 2.70 and $5.41 \%$, respectively.

The duration of the nymphal stage was 16,9 and 8 days at temperatures of 15,20 and $25^{\circ} \mathrm{C}$, respectively, and 11 days for those individuals maintained in the greenhouse (Table 1). The highest mortality rate of this aphid

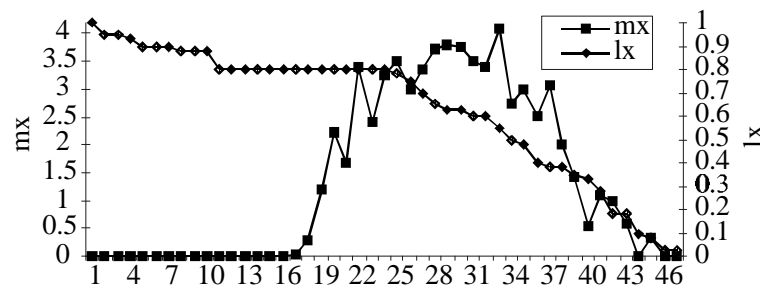

B1 Time (days)
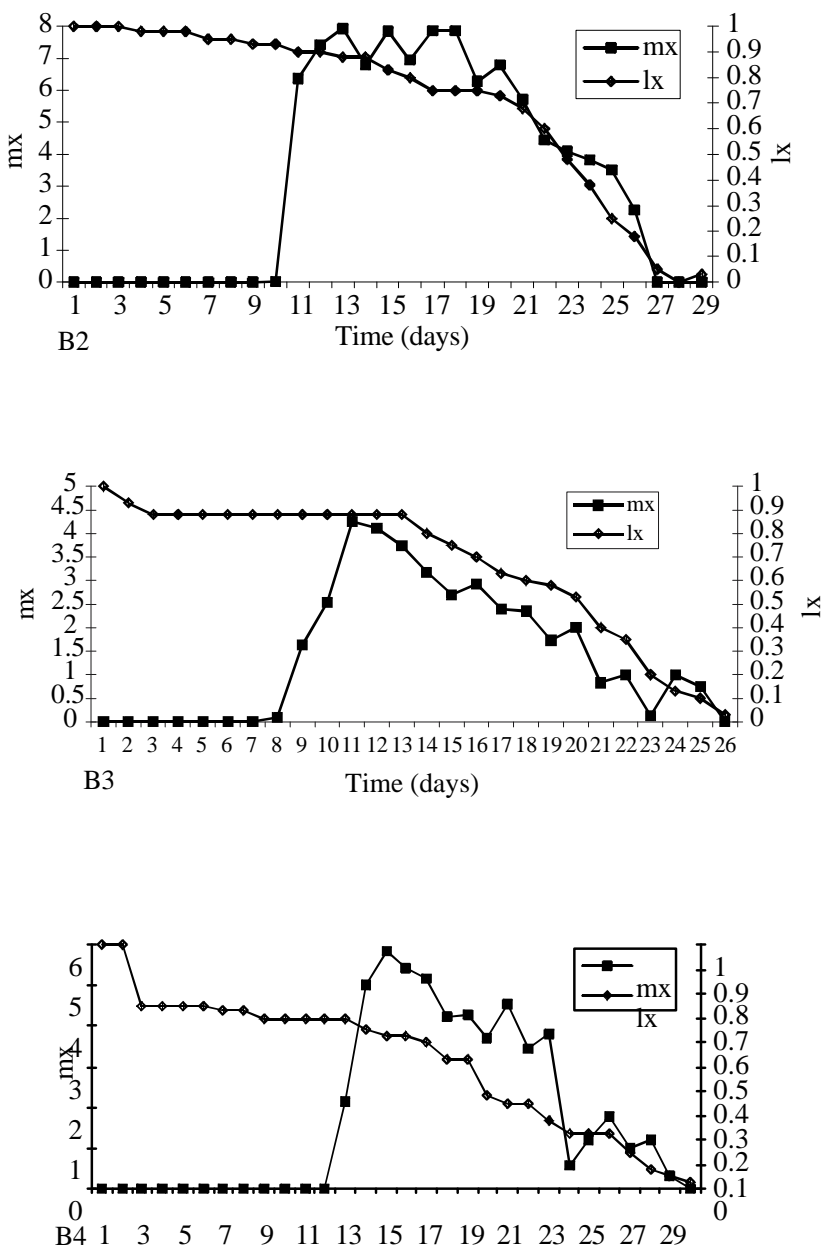

Figure 1 - Survivorship (Lx) and life expectancy (ex) (A1, A2, A3, A4), mean number of mymphs/female (mx) and percentage of survival (lx) (B1, B2, B3, B4) of Uroleucon ambrosiae at constant temperatures of 15,20 , and $25^{\circ} \mathrm{C}$, and in the greenhouse at a mean temperature of $21^{\circ} \mathrm{C}$, respectively. 
species at the nymphal stage was verified when they were under greenhouse conditions. In the laboratory, the highest mortality occurred at $15^{\circ} \mathrm{C}$ (Figure 1). The influence of temperature on the life table parameters of Toxoptera aurantii (Boyer de Fonscolombe) was mentioned by Wang \& Tsai (2001) and followed the same trend observed in the present study.

\section{Fertility table}

At $15^{\circ} \mathrm{C}$ the greatest age-specific fertility $\left(\mathrm{m}_{\mathrm{x}}\right)$ occurred between 32 and 35 days (4.09 nymphs per female per day) (Figure 1). The age-specific survival $\left(1_{x}\right)$ started to decline beginning on day 1.5 , stabilizing above $80 \%$ until day 22.5. From this evaluation forth, gradual decreases were observed, reaching $50 \%$ on day 32.5 (Figure 1). The mean duration of $U$. ambrosiae generations (T) was 27.66 days, with a net reproductive rate $\left(R_{o}\right)$ of 39.56. The finite rate of increase $(\lambda)$ was 1.13 nymphs per female per day. The lowest intrinsic rate of population increase $\left(\mathrm{r}_{\mathrm{m}}=0.13\right)$ was verified at $15^{\circ} \mathrm{C}$ (Table 2). Even though the aphids maintained at this temperature had greater increase in population density from one generation to the next, they had a lower growth potential when compared to kept aphids at $25^{\circ} \mathrm{C}$ and at room temperature (greenhouse), manifested by their intrinsic rate of population increase. Similar values were verified by Wang \& Tsai (2001) while studying the life table for $T$. aurantii at a constant temperature of $15^{\circ} \mathrm{C}$.

The production of 1.28 nymphs per female per day, the time necessary for the population to double in size ( 2.77 days) and the intrinsic rate of population increase $(0.25)$, were the same when insects were maintained at 20 and $25^{\circ} \mathrm{C}$ (Table 2). Therefore, the optimal temperature for the best increase in population density of $U$. ambrosiae is within this interval. In reports of Van Steenis \& El-Khawass (1995) with A. gossypii, Godoy (1999) with L. erysimi, and Wang \& Tsai (2001) with $T$. aurantii, an increase in $\mathrm{r}_{\mathrm{m}}$ was recorded for aphids with increasing temperature, but the opposite was observed by Goel \& Singh (1994) for L. erysimi. These differences can be attributed to the intrinsic characteristics of the aphid species investigated or to differences in the experimental conditions. However, at $20^{\circ} \mathrm{C}$, higher values were verified for the interval between generations $(\mathrm{T})$ and for the net reproductive rate $\left(\mathrm{R}_{0}\right)$. Nowierski et al. (1995) recorded a higher $\mathrm{R}_{0}$ value (42.08) for Diuraphis noxia (Nowierski) at $25^{\circ} \mathrm{C}$, as compared to temperatures of $10^{\circ} \mathrm{C}$ (15.89) and $30^{\circ} \mathrm{C}$ (9.16).

The time necessary for the population to double in size was shorter at 20 and $25^{\circ} \mathrm{C}$ (2.77 days), in comparison to the other temperatures. Females maintained at $15^{\circ} \mathrm{C}$ spent twice as long, on average 5.33 days, to double their population (Table 2 ).

In the greenhouse, in spite of the fact that the interval between generations was similar to that ob- served in the laboratory at 20 and $25^{\circ} \mathrm{C}$, parameters $\mathrm{R}_{0}, \mathrm{r}_{\mathrm{m}}$ and $\lambda$ were lower and TD was higher. The net reproductive rate $\left(R_{0}\right)$ allowed to determine that $U$. ambrosiae has, an increased capacity of 25.79 fold from one generation to the next, quite lower than the value verified in the laboratory at a constant temperature of $20^{\circ} \mathrm{C}$, i.e., 70.02 (Table 2). Auad et al. (2002) mentioned that the highest $U$. ambrosiae population densities in the greenhouse on hydroponic lettuce were recorded when the temperature was between 16.4 and $19.2^{\circ} \mathrm{C}$.

From the biological aspects, fertility and life expectancy tables, the constant temperature of $20^{\circ} \mathrm{C}$ is the most suitable for $U$. ambrosiae, and some differences can be observed when the nymphs are reared in the greenhouse, under a mean temperature near $21^{\circ} \mathrm{C}$, although with marked variation. This information is important for studies involving population dynamics of this aphid, allowing the estimation of aspects related to its population growth potential, in order to provide background knowledge for management strategies against this pest insect on hydroponic lettuce.

\section{REFERENCES}

AKASHE, V.B.; DEOKAR, C.D.; PATIL, M.W.; SHEWATE M.R. Seasonal incidence of aphid Uroleucon compositae in safflower. Madras Agricultural Journal, v.82, p.232-233, 1995.

AUAD, A.M.; FREITAS, S.; BARBOSA, L.R. Ocorrência de afídeos em alface (Lactuca sativa) em cultivo hidropônico. Neotropical Entomology, v.31, p.335-339, 2002.

BLACKMAN, R.L. Reproduction, cytogenetics and development. In: MINKS, A.K.; HARREWINJN, P. World crop pests. Aphids: Their biology, natural enemies and control. Amsterdam: Elsevier, 1987. cap.2, p.163-196.

BUENO, V.H.P.; FOUREAUX, L.V. Effect of different temperature on the biology of Brachycaudus (Appelia) schwartzi (Aphididae) and thermal requeriments. In: Aphids in natural and managed ecosystems. NIETO NAFRIA, J.M.; DIXON, A.F.G. (eds.) Leon, Spain, 1998. p.133-137.

DAROLD, M.R.; BIANCO NETO, V.; ZAMBOM, F.R.A. Cinza vegetal como fonte de nutriente e corretivo de solo na cultura da alface. Revista da Sociedade Brasileira de Olericultura, v.1, p.35-40, 1993.

DIXON, A.F.G. Parternogenetic reproduction and the rate of increase in aphids. In: MINKS, A.K.; HARREWINJN, P. World crop pests. Aphids: Their biology, natural enemies and control. Amsterdam: Elsevier, 1987. cap.4, p.269-287.

ELLIOTT, N.C.; KIECKHEFER, R.W. Effects of constant and fluctuating temperatures on immature development and age-specific life tables of Rhopalosiphum padi (L.) (Homoptera: Aphididae). The Canadian Entomologist, v.21, p.131-140, 1989.

GODOY, K.B. Exigências térmicas e tabelas de fertilidade e esperança de vida de Lipaphis erysimi (Kaltenbach, 1843) (Homoptera: Aphididae). Jaboticabal: UNESP/FCA, 1999. 70p. (Dissertação - Mestrado)

GOEL, S.C.; SINGH. B. The intrinsic rate of natural increase and the life expectancy of Lipaphis erysimi (Kalt.) on mustard in India. Insect Science and its Application, v.15, p.287-291, 1994

KOCOUREX, F.; HAVELKA, J.; BERANKOVA, J.; JAROSIK, V. Effect of temperature on development rate and intrinsic rate of Aphis gossypii reared on greenhouse cucumbers. Entomologia Experimentalis et Applicata, v.71, p.59-64, 1994.

LIU, S.S.; MENG, X.D. Modelling development time of Myzus persicae (Hemiptera: Aphididae) at constant and natural temperatures. Bulletin of Entomological Research, v.89, p.53-63, 1999. 
LIU, S.S.; MENG, X.D. Modelling development time of Lipaphis erysimi (Hemiptera: Aphididae) at constant and variable temperatures. Bulletin of Entomological Research, v.90, p.337-347, 2000.

NOWIERSKI, R.M.; ZHENG, Z.; SCHAREN, A.L. Age-specific life table modeling of the russian wheat aphid (Homoptera: Aphididae) on barley grown in benzimidazole agar. Environmental Entomology, v.24, p.1284-1290, 1995.

PEÑA-MARTINEZ, R. Identificacion de afidos de importancia agricola In: URIAS, C.M.; RODRIGUEZ, R.M.; ALEJANDR, T.A. Afidos como vetores de vírus en México. Montecillo: Centro de Fitopatologia, 1992, $135 \mathrm{p}$.

SILVEIRA NETO, S.; NAKANO, O.; BARBIN, D.; VILLA NOVA, N. Manual de ecologia dos insetos. São Paulo: Agronômica Ceres, 1976. 419p.
VAN STEENIS, M.J.; EL-KHAWASS, K.A.M.H. Life history of Aphis gossypii on cucumber: Influence of temperature, host plant and parasitism. Entomologia Experimentalis et Applicata, v.76, p.121-131, 1995.

WANG, J.J.; TSAI, J.H. Development, survival and reproduction of black citrus aphid, Toxoptera aurantii (Hemiptera: Aphididae), as a function of temperature. Bulletin of Entomological Research, v.91, p.477-487, 2001.

Received July 22, 2002

Accepted August 12, 2003 